\title{
ESTIMASI HAMBUR BALIK DASAR PERAIRAN DAN SUMBER DAYA IKAN DEMERSAL MENGGUNAKAN METODE HIDROAKUSTIK
}

\author{
Sri Pujiyati'1), Wijopriono'), Mahiswara2), Bonar P. Pasaribu ${ }^{3)}$, \\ Indra Jaya ${ }^{3)}$, dan Djisman Manurung ${ }^{3)}$ \\ 1) Mahasiswa pada Program Doktor Sekolah Pascasarjana-Institut Pertanian Bogor, Bogor \\ 2) Peneliti pada Balai Riset Perikanan Laut, Muara Baru-Jakarta \\ 3) Staf Pengajar pada Departemen Ilmu dan Teknologi Kelautan-Fakultas Perikanan dan IImu Kelautan-Institut Pertanian Bogor, Bogor \\ Teregristrasi I tanggal: 6 Nopember 2006; Diterima setelah perbaikan tanggal: 15 Mei 2007; Disetujui terbit tanggal: 18 Juli 2007
}

\begin{abstract}
ABSTRAK
Survei hidroakustik dilakukan pada bulan Oktober 2002 dengan menggunakan kapal penelitian Mutiara IV (115,19 GT) milik Balai Riset Perikanan Laut, Muara Baru-Jakarta. Alat hidroakustik yang digunakan adalah echosounder EY-500 dengan program pengolahan data EP-500, menu analisis expanded bottom dan bottom layer. Data yang diperoleh adalah nilai back scattering volume dari dasar perairan yang selanjutnya disebut dengan hambur balik dasar perairan, target strength dan densitas ikan demersal dilengkapi dengan data trawl untuk verifikasi. Tujuan penelitian ini adalah untuk mengetahui nilai hambur balik dasar perairan, dan penyebaran ikan demersal secara hidroakustik. Penyebaran nilai hambur balik dasar perairan sepanjang lintasan penelitian yang diperoleh berkisar antara -38,29 sampai dengan -20,02 $\mathrm{dB}$, dengan rata-rata $-28,09 \mathrm{~dB}$. Kisaran nilai target strength dari $-51,00$ sampai dengan $-24,01 \mathrm{~dB}$, dengan rata-rata $-41,11 \mathrm{~dB}$, adapun nilai densitas ikan berkisar 0,001 sampai dengan $1,640 \mathrm{~g} \mathrm{~m}^{-3}$ dengan rata-rata $0,342 \mathrm{~g} \mathrm{~m}^{-3}$.
\end{abstract}

KATAKUNCI: survei hidroakustik, EP-500, densitas, ikan demersal

ABSTRACT: Estimation of sea bottom reflection and fish demersal resources using hydro acoustical method. By: Sri Pujiyati, Wijopriyono, Mahisworo, Bonar P. Pasaribu, Indra Jaya, and Djisman Manurung

Hydroacoustic survey was conducted in October 2002 by using research vessel Mutiara IV (115,19 GT) owned by Marine Fishery Research Institute, Ministry of Marine Affairs and Fisheries. The hydroacoustic apparatus used echousounder EY-500, used software EP-500 for data processing with menu for analyzing the expanded bottom and bottom layer. The obtained data were backscattering volume as sea bottom reflection, target strength and density of demersal fish. The research objectives are to analyze the sea bottom reflection and to explore demersal fish resources by hydroacoustic method. The distribution of sea bottom reflection along cruising area ranges between $-38,29$ to $-20,02 \mathrm{~dB}$, with average value of $-28,09 \mathrm{~dB}$. The range of target strength values is distributed between $-51,00$ and $-24,01 \mathrm{~dB}$, with and the average of target strength $-41,11 \mathrm{~dB}$. The density of fish ranges between $0,00 \mathrm{~dB}$ until $1,64 \mathrm{~g} \mathrm{~m}^{-3}$ with $0,33 \mathrm{~g} \mathrm{~m}^{-3}$ in average.

\section{KEYWORDS: $\quad$ survey hydroacoustic, EP-500, density, demersal fish}

\section{PENDAHULUAN}

Metode hidroakustik merupakan salah satu metode yang dapat digunakan dalam eksplorasi sumber daya ikan demersal. Selain itu, untuk mendeteksi ikan demersal, metode ini juga dapat digunakan untuk mendeteksi dasar perairan. Manik (2006) melakukan penelitian untuk mengobservasi habitat ikan demersal di perairan selatan Jawa, dengan menggunakan echosounder frekuensi 38. Hasil menunjukkan volume back scattering strength dasar perairan berkisar -70 sampai dengan $-10 \mathrm{~dB}$, dan nilai scattering volume dari ikan yang berada dekat dasar perairan berkisar -60,00 sampai dengan $-30,00 \mathrm{~dB}$. Siwabessy (2001) telah melakukan penelitian pada beberapa lokasi penelitian yang berbeda dan menunjukkan bahwa estimasi densitas ikan demersal dengan menggunakan hidroakustik pada frekuensi $38 \mathrm{KHz}$ signifikan dengan hasil tangkapan trawl.

Tujuan penelitian ini adalah untuk mengetahui nilai hambur balik dasar perairan, dan penyebaran ikan demersal secara hidroakustik.

\section{BAHAN DAN METODE}

Penelitian ini dilakukan di perairan Laut Jawa oleh tim dari Balai Riset Perikanan Laut, pada bulan Oktober 2002 dengan menggunakan Kapal Riset Mutiara 4.

Kosrespondensi penulis: 
Peralatan yang dipergunakan adalah seperangkat hidroakustik EY-500 frekuensi $38 \mathrm{KHz}$. Selain itu, peralatan hidroakustik juga dilengkapi pula alat penangkapan ikan jenis traw/ dasar yang berukuran kecil untuk verifikasi data hidroakustik, dan GPS.

Lintasan survei menggunakan bentuk campuran yaitu bentuk paralel dan zig-zag. Pengambilan data meliputi data hidroakustik yang direkam sepanjang lintasan survei dan sapuan trawlyang dilakukan pada 20 stasiun (Gambar 1).

Data hidroakustik yang didapat berupa data echogram yang dikompres dalam bentuk data treshold, kemudian data dasar perairan dianalisis menggunakan program pengolahan EP-500 dengan menu expanded bottom untuk mendapatkan nilai scattering volume dari dasar perairan yang kemudian disebut hambur balik dasar perairan. Analisis dengan menu bottom layer untuk mendapatkan nilai target strength yang merupakan pantulan dari sasaran tunggal dan scattering volume ikan yang merupakan pantulan dari gerombolan ikan, yang nanti digunakan untuk menghitung densitas ikan. Pengolahan data dilanjutkan dengan menggunakan program surfer untuk melihat sebaran secara horisontal, dan ditabelkan untuk mendapatkan nilai rata-rata hambur balik dasar perairan, target strength dalam selang kelas kedalaman.

Pengoperasian alat tangkap trawl di 20 stasiun untuk mendapatkan data komposisi hasil tangkapan menurut jenis ikan, kemudian dicari jenis ikan yang dominan, dan frekuensi kemunculan di setiap stasiun. Data komposisi selanjutnya dikelompokkan berdasarkan pada selang kelas kedalaman, sehingga diperoleh jenis ikan dominan dan densitas ikan di setiap selang kelas kedalaman. Data jenis ikan di setiap selang kelas kedalaman dianalisis lebih lanjut dengan analisis korespondensi untuk menggambarkan kemiripan spesies ikan pada selang kelas kedalaman.

Proses perhitungan nilai target strength diperoleh berdasarkan pada:

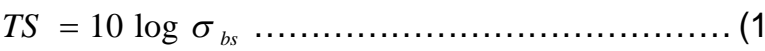

$$
\begin{aligned}
& \sigma_{b s}=10^{0,1 T S} \\
& \sigma_{b s} \text { adalah target back scattering cross section. Nilai }
\end{aligned}
$$

back scattering volume diperoleh dari intensitas suara yang mengenai sasaran pada volume air tertentu $\left(\mathrm{m}^{3}\right)$ yang diperoleh dari persamaan berikut:

$$
S V=S_{A} /\left(\left(4 \pi R_{o}^{2}(1852 m / n m)^{2}\left(r_{2}-r_{1}\right)\right) \ldots \ldots\right. \text { (3 }
$$

di mana:

$\mathrm{S}_{\mathrm{A}}=$ back scattering area

$r_{2}-r_{1}=$ ketebalan kolom integrasi

$R_{o}=$ jarak referensi $(1 \mathrm{~m})$

Nilai back scattering volume dapat juga diperoleh dari:

$$
S V=10 \log \rho v+T S
$$

sehingga densitas ikan (ekor $\mathrm{m}^{-3}$ ) untuk suatu integrasi dapat diperoleh apabila target strength dan scattering volume diketahui.

$$
\begin{aligned}
& 10 \log \rho v=S V-T S_{r} \\
& \rho v=10^{0,1\left(S V-T S_{\text {rata-rata }}\right)}
\end{aligned}
$$

dengan persamaan-persamaan di atas, maka dapat dilakukan modifikasi dari densitas (ekor $\mathrm{m}^{-3}$ ) menjadi densitas $\left(\mathrm{g} \mathrm{m}^{3}\right.$ ) yaitu dengan mengalikan densitas (ekor $\mathrm{m}^{-3}$ ) dengan bobot rata-rata ikan dominan.

$$
\rho v=10^{0,1(S V-T S)} \cdot w
$$

di mana:

$\rho v=$ densitas $\left(\mathrm{g} \mathrm{m}^{-3}\right)$

$S V=$ Back scattering volume $(d B)$

$T S=$ Target strength $(d B)$

$w=$ Bobot rata-rata ikan yang dominan $(\mathrm{g})$

Survei hidroakustik maupun sapuan trawl memiliki kedalaman perairan yang berbeda, sehingga perlu dianalisis lebih lanjut yaitu berdasarkan pada selang kelas kedalaman. Pembagian selang kelas kedalaman dengan mempergunakan rumus (Nasoetion \& Barizi, 1985):

$$
1+3,3 \log n
$$

di mana:

$\mathrm{n}$ = jumlah data hidroakustik yaitu 259 sehingga diperoleh 9 selang kelas kedalaman perairan yaitu 1) <29,50 m;2) 29,60 sampai dengan 36,50 $\mathrm{m}$; 3) 36,60 sampai dengan 43,50 m; 4) 43,60 sampai dengan $50,50 \mathrm{~m}$; 5) 50,60 sampai dengan $57,50 \mathrm{~m}$; 6) 57,60 sampai dengan $64,50 \mathrm{~m}$; 7) 64,60 sampai dengan $71,50 \mathrm{~m}$; 8) 71,60 sampai dengan 78,50 m; dan 9) >78,60 m. 


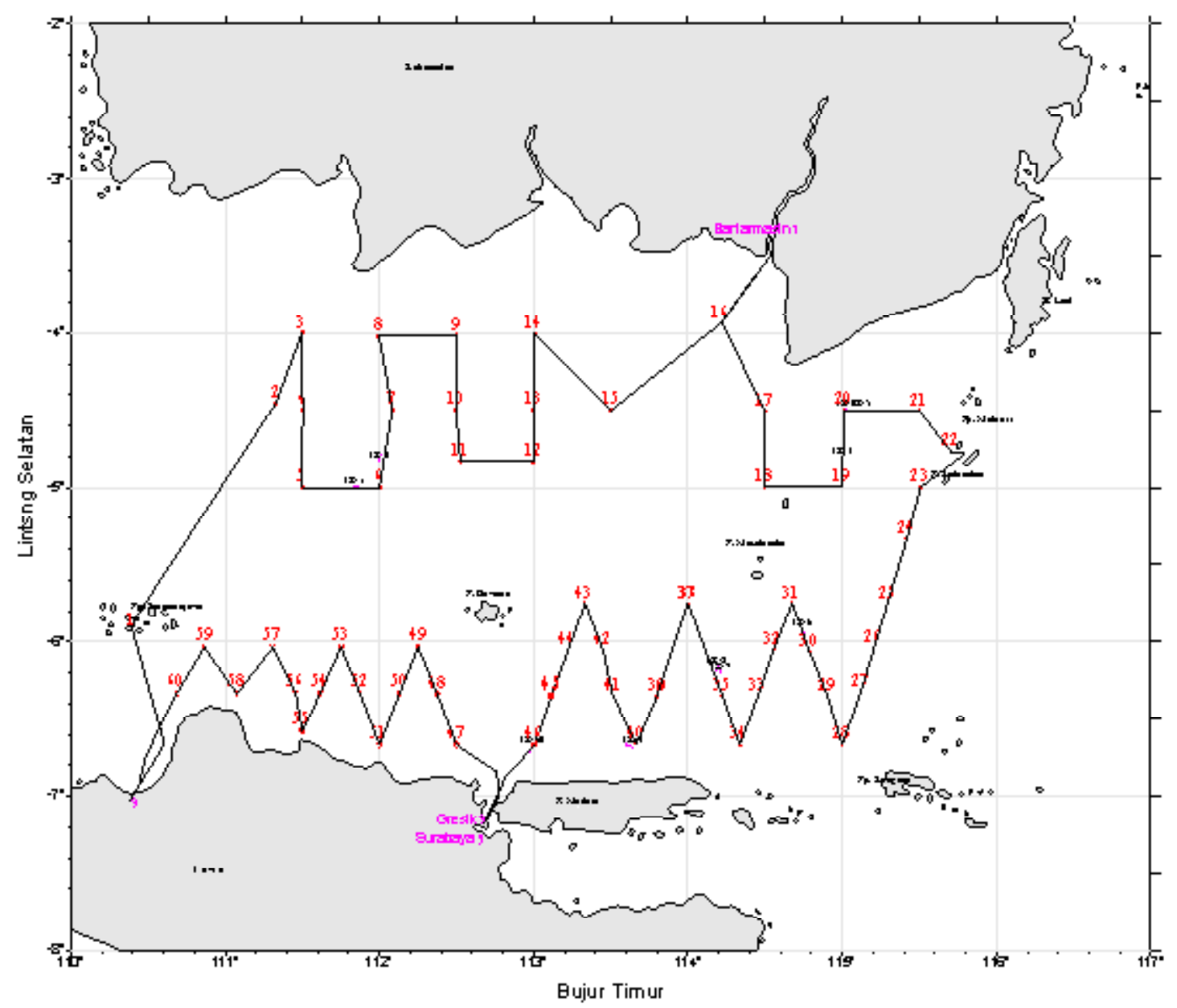

Gambar 1. Lintasan survey.

Figure 1. Survey track.

\section{HASIL DAN BAHASAN}

\section{Penyebaran Nilai Hambur Balik Dasar Perairan}

Berdasarkan pada data pengambilan substrat dasar perairan pada tahun 1974 sampai dengan 1979 menunjukkan bahwa substrat dasar perairan di Laut Jawa didominasi oleh substrat lumpur (Emery et al.,1972 dalam Sadhotomo, 2006). Substrat ini bila dideteksi dengan metode hidroakustik diperoleh nilai kisaran hambur balik dasar perairan yaitu $-20,02$ sampai dengan $-38,29 \mathrm{~dB}$, dengan rata-rata $-28,09 \mathrm{~dB}$ dan simpangan baku 3,35 (Gambar 2).
Penyebaran nilai hambur balik merata di sepanjang lintasan survei. Pada lokasi mendekati Pulau Kalimantan nilai hambur balik dasar perairan cukup besar sampai dengan $-25,00 \mathrm{~dB}$, namun semakin ke arah selatan mendekati pantai utara Jawa nilai hambur balik semakin kecil. Besar nilai di selatan Kalimantan diduga ada lahan berkarang atau berpasir seperti yang dikemukakan oleh Wirtky (1961) bahwa di selatan Pulau Kalimantan terdapat lahan berpasir. Nilai Hambur balik dasar perairan di Laut Jawa -20,02 sampai dengan -38,29 dB berada pada kisaran nilai yang diperoleh.

Manik (2006) bahwa deteksi volume back scattering strength di perairan selatan Jawa berkisar $-70,00$ sampai dengan $-10,00 \mathrm{~dB}$. 


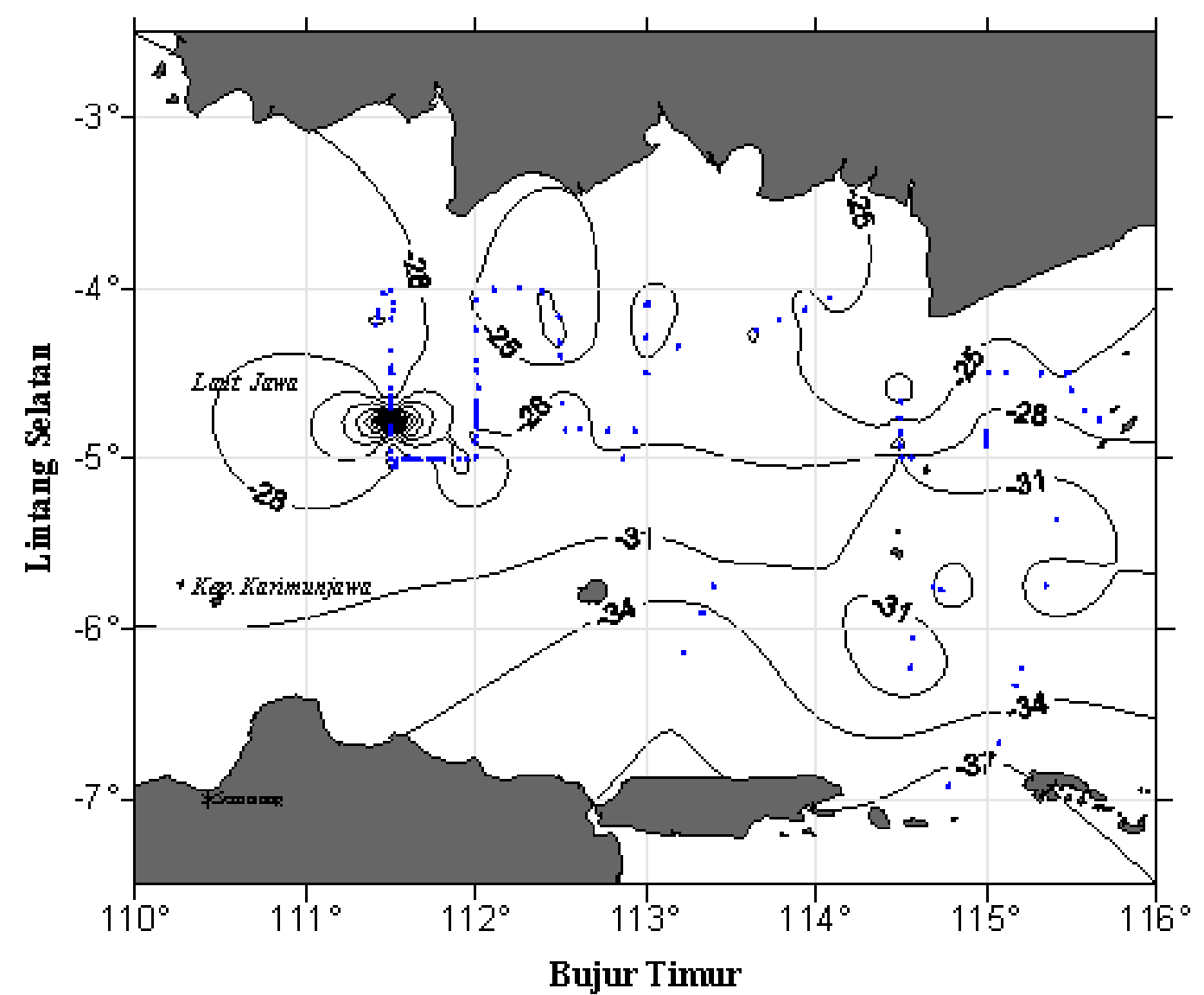

Gambar 2. Distribusi horisontal hambur balik dasar perairan.

Figure 2. Horizontal distribution of sea bottom reflection.

\section{Penyebaran Nilai Target Strength dan Densitas Ikan secara Hidroakustik}

Hasil data hidroakustik menunjukkan kisaran nilai target strength menyebar dari $-51,00$ sampai dengan $24,00 \mathrm{~dB}$, dengan jumlah total sasaran tunggal yang terdeteksi 4.310 ekor. Jumlah ikan terbanyak pada nilai target strength $-48,00 \mathrm{~dB}$ yaitu 1.883 ekor, disusul nilai target strength $-51,00 \mathrm{~dB} 1.004$ ekor dan urutan ke-3 $45 \mathrm{~dB} 831$ ekor, ini menunjukkan ikan-ikan ukuran besar semakin berkurang jumlah. Rata-rata target strength di seluruh perairan $-41,11 \mathrm{~dB}$, nilai ini mengindikasikan ikanikan yang ada di perairan adalah ikan-ikan kecil. Hal ini, didukung dengan hasil sapuan traw/pada penelitian ini yang menunjukkan ikan peperek mendominasi sapuan trawl (lihat tentang komposisi dan distribusi ikan demersal hasil sapuan traw). Ikan peperek ini memiliki panjang total $10,24 \mathrm{~cm}$. Jika dibandingkan antara nilai rata-rata target strength dalam penelitian ini dengan nilai target strength ikan demersal yang terdeteksi di perairan Serawak pada tahun 1996 dan 1997 tidak jauh berbeda yaitu -43,2 dB (Rajali et al., 2006). Manik (2006) mengatakan nilai back scattering volume ikan yang berada pada dekat dasar laut di perairan selatan Jawa berkisar $-60,00$ sampai dengan $-30,00 \mathrm{~dB}$. Kisaran nilai target strength ini tidak jauh berbeda dengan kisaran target strength di Laut Jawa. Penyebaran nilai target strength sepanjang lintasan survei menunjukkan semakin menjauhi pantai, nilai target strength cenderung semakin besar (Gambar 3). 


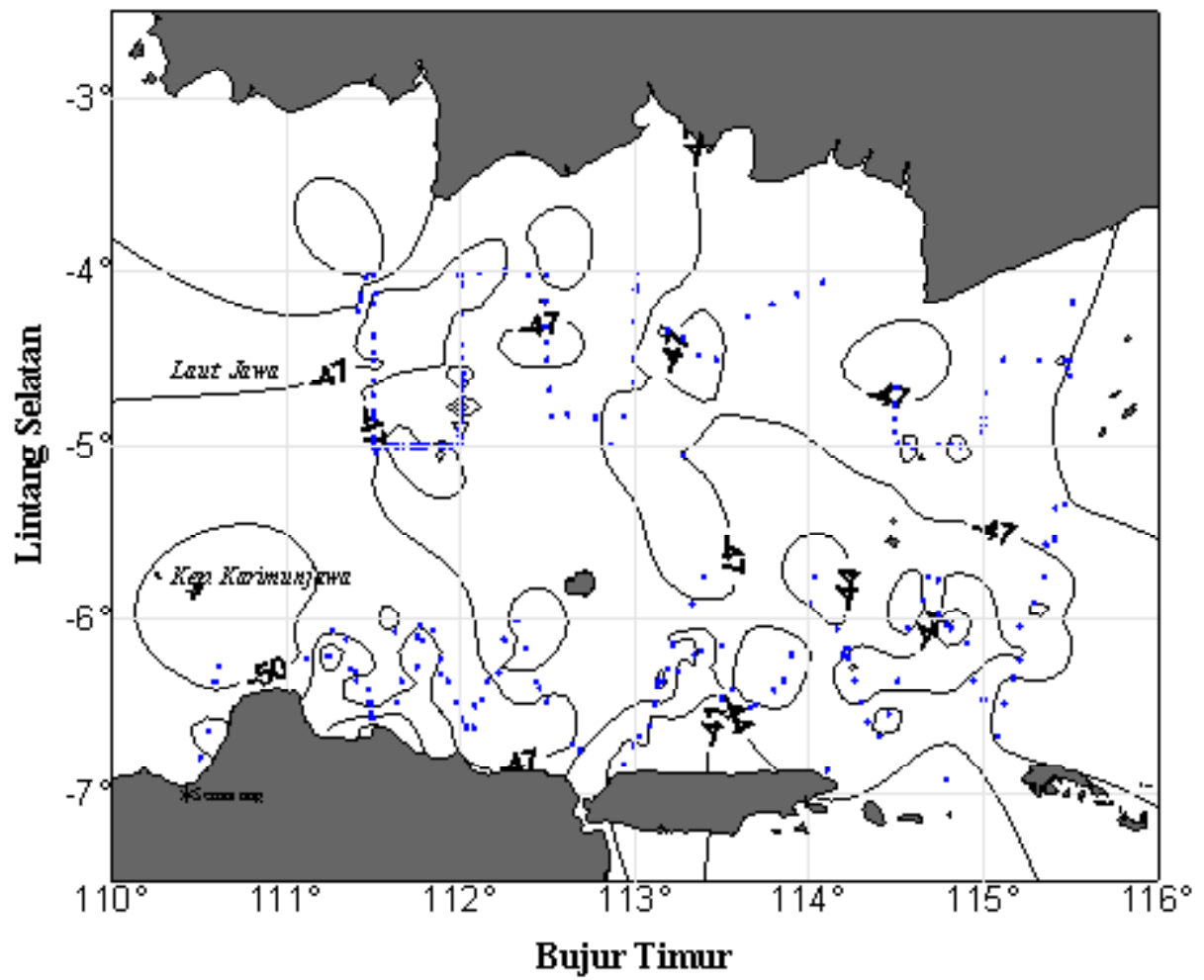

Gambar 3. Distribusi horisontal target strength.

Figure 3. Horizontal distribution of target strength.

Berdasarkan pada data densitas hasil deteksi hidroakustik diperoleh informasi bahwa densitas berkisar dari 0,001 sampai dengan $1,640 \mathrm{~g} \mathrm{~m}^{-3}$ dengan rata-rata $0,342 \mathrm{~g} \mathrm{~m}^{-3}$. Densitas ikan lebih dari $0,500 \mathrm{~g} \mathrm{~m}^{-3}$ di lokasi perairan dangkal dan mendekati pantai. Lokasi yang dalam seperti di lokasi Laut Jawa bagian timur di utara Pulau Kangean memiliki densitas relatif rendah (Gambar 4). Nilai densitas ikan demersal yang relatif rendah juga diperoleh dalam penelitian di perairan Sarawak yaitu 0,300 sampai dengan $1,830 \mathrm{~g} \mathrm{~m}^{-3}$.
Berdasarkan pada penyebaran nilai densitas ikan secara horisontal, terlihat dengan menjauhi pantai menuju ke tengah perairan, densitas ikan menurun dengan bertambah kedalaman. Badrudin (2004) juga mengatakan bahwa kedalaman perairan berpengaruh terhadap penyebaran ikan demersal. Labropoulou \& Papaconstantianous (2004) mengatakan densitas ikan tinggi pada kedalaman 25 sampai dengan $32 \mathrm{~m}$. Ridho et al. (2002) mengatakan bahwa selain kedalaman, oksigen terlarut ikut memberi pengaruh terhadap penyebaran ikan demersal. 


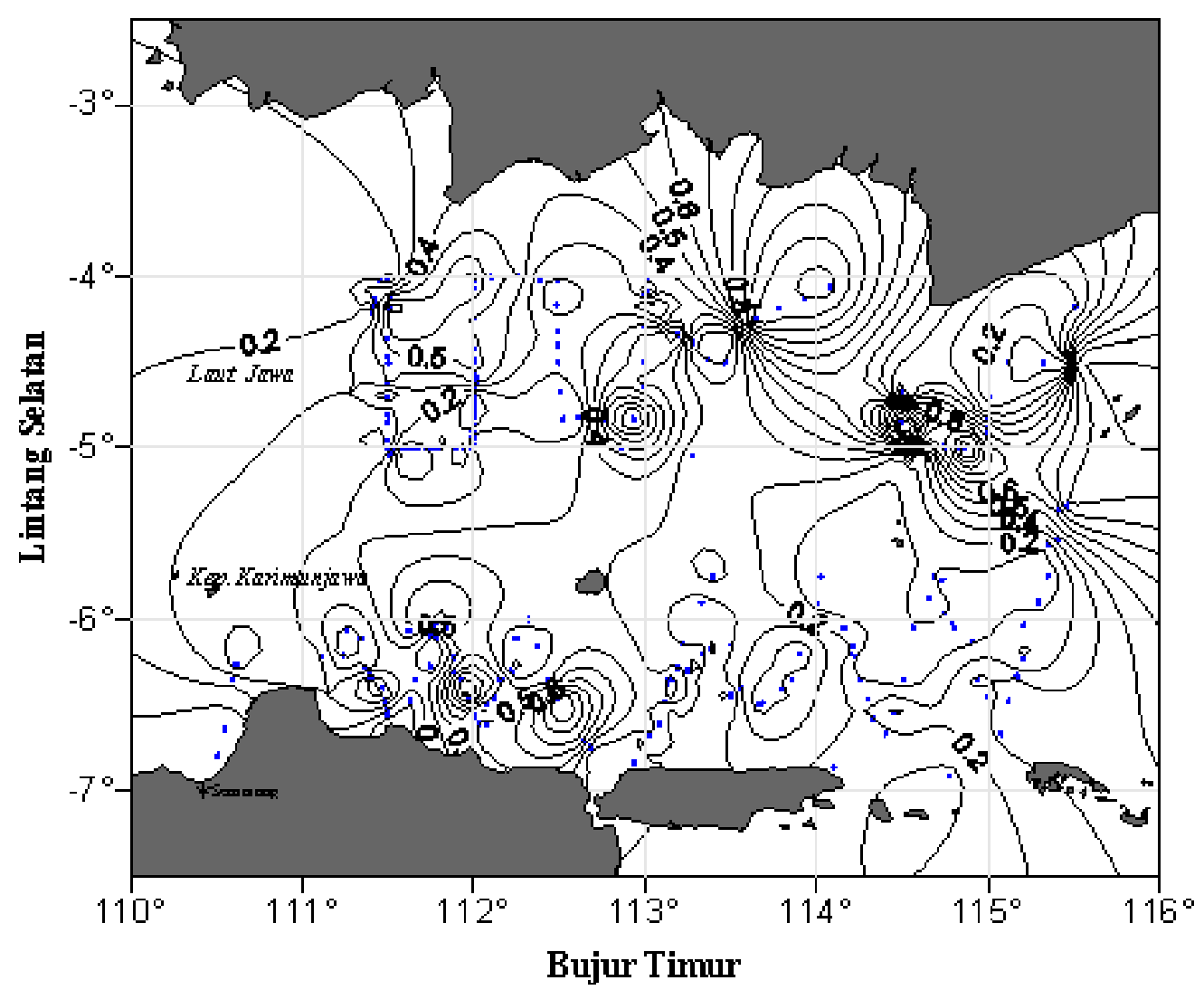

Gambar 4. Distribusi horisontal densitas ikan.

Figure 4. Horizontal distribution of fish density.

Komposisi dan Distribusi Ikan Demersal Hasil Sapuan Trawl

Total hasil sapuan lahan yang diperoleh dengan menggunakan alat tangkap traw/ dasar (bottom traw) di 20 stasiun penelitian dengan kedalaman perairan yang beragam, diperoleh data sebagai berikut ditemukan 39 famili, dengan 91 spesies ikan demersal dan total hasil sapuan $953,81 \mathrm{~kg}$. Stasiun-stasiun yang memiliki hasil sapuan terbesar yaitu stasiun 5,6 , dan 14 , stasiunstasiun ini memiliki kedalaman yang cukup dangkal yaitu 24,4 dan 26,8 m, namun untuk stasiun 14 berkedalaman sampai dengan $42 \mathrm{~m}$ (Gambar 5). Ona et al. (1990) mengatakan bahwa pada perairan yang dangkal, ikan akan lebih terkonsentasi dekat dasar perairan, dan dengan pengoperasian traw/dasar memberikan hasil yang memuaskan.

Jenis ikan yang memiliki jumlah tangkapan lebih dari $40 \mathrm{~kg}$ antara lain spesies peperek (Leiognathus splendens) dan kurisi (Nemipterus hexodon) (Gambar 6). Ikan peperek (Leiognathus splendens) merupakan spesies terbanyak tertangkap (mendominasi sapuan), dan spesies beloso (Surida undosquamis) merupakan spesies yang muncul paling banyak di seluruh stasiun sapuan (19 stasiun). 


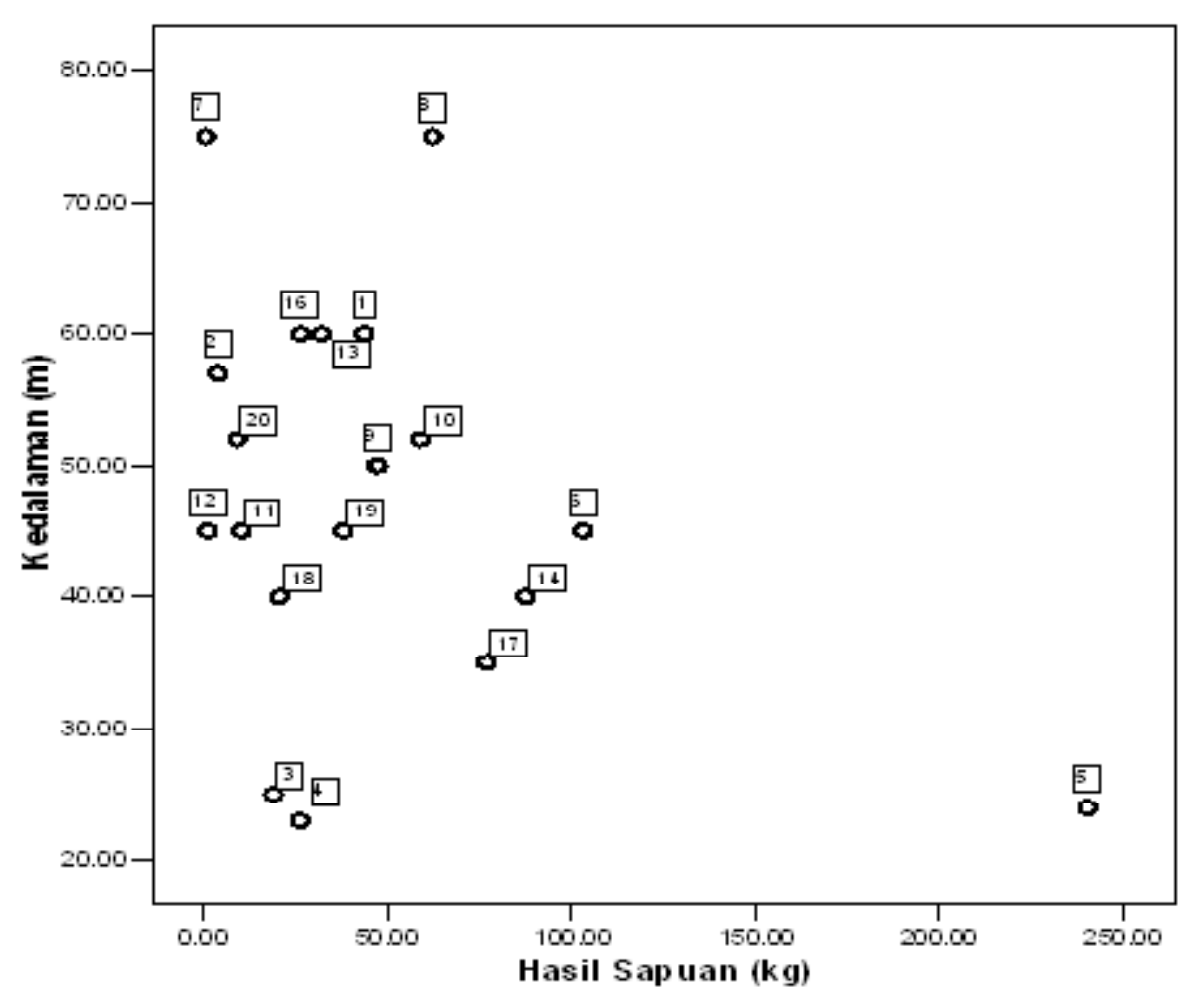

Gambar 5. Total sapuan ikan demersal berdasarkan pada kedalaman.

Figure 5. Total swept area of demersal fish based on depth.

Keterangan/Remarks. 1 nomor stasiun trawl
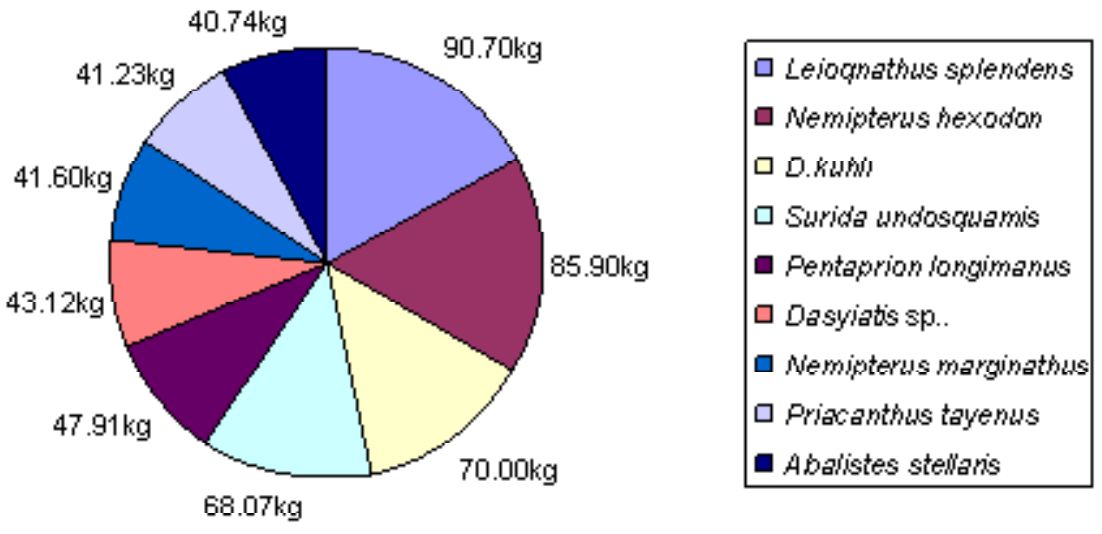

Gambar 6. Spesies ikan demersal yang mendominasi sapuan trawl.

Figure 6. Demersal fish species dominance of swept area.

Ikan peperek yang mendominasi sapuan di perairan Laut Jawa memberikan informasi yang sama dibandingkan spesies hasil sapuan trawl di perairan Malaka pada bulan Agustus 2003 (Hufiadi \& Nurdin, 2006), dan fenomena yang sama juga ditemukan di perairan Laut Cina Selatan (Sumiono et al., 2003). Sementara itu, spesies beloso (Saurida undosquamis) ditemukan pada $95 \%$ stasiun pengoperasian trawl, menunjukkan bahwa jenis ini dapat beradaptasi di seluruh perairan. 
Nilai Hambur Balik Dasar Perairan dengan Ikan Demersal Hasil Deteksi Hidroakustik maupun Sapuan Trawl di Setiap Selang Kelas Kedalaman

Berdasarkan pada informasi bahwa ikan demersal penyebaran dipengaruhi oleh kedalaman, maka selanjutnya dibahas mengenai pengaruh selang kelas kedalaman terhadap ikan demersal hasil deteksi hidroakustik maupun sapuan trawl (Tabel 1).
Tabel 1 menggambarkan nilai hambur balik dasar perairan memiliki ukuran paling besar di perairan dangkal (<36,50 m). Namun, besar nilai hambur balik dasar perairan ini tidak diikuti oleh besar nilai target strength ikan. Hal ini, menunjukkan ikan yang berukuran kecil (nilai target strength paling kecil) menyukai daerah dangkal dan dengan tipe substrat yang lebih keras (nilai hambur balik besar). Ikan-ikan tersebut ternyata memiliki densitas yang tinggi berdasarkan pada sapuan trawl, dan merupakan jenis peperek dan kurisi.

Tabel 1. Data rata-rata hambur balik dasar perairan, target strength, dan densitas ikan pada selang kelas kedalaman

Table 1. Average of sea bottom reflection, target strength, and fish density at depth class range

\begin{tabular}{|c|c|c|c|c|c|}
\hline $\begin{array}{c}\text { Selang } \\
\text { kelas } \\
\text { kedalaman/ } \\
\text { Range of } \\
\text { depth }\end{array}$ & $\begin{array}{l}\text { Rata-rata } \\
\text { hambur balik } \\
\text { dasar perairan/ } \\
\text { Average of } \\
\text { bottom } \\
\text { reflection } \\
\text { (dB) }\end{array}$ & $\begin{array}{c}\text { Rata-rata } \\
\text { target strength } \\
\text { ikan demersal/ } \\
\text { Average of } \\
\text { strenght highest } \\
\text { for fish demersal } \\
\text { (dB) }\end{array}$ & $\begin{array}{c}\text { Rata-rata } \\
\text { densitas ikan } \\
\text { demersal } \\
\text { hidroakustik/ } \\
\text { Average of } \\
\text { hydroacoustic } \\
\text { demersal fish } \\
\text { density (g m } 3 \text { ) }\end{array}$ & $\begin{array}{c}\text { Rata-rata } \\
\text { densitas ikan } \\
\text { demersal } \\
\text { hasil sapuan/ } \\
\text { Average of } \\
\text { swept area } \\
\text { demersal fish } \\
\text { density (g m³) }\end{array}$ & $\begin{array}{l}\text { Spesies } \\
\text { dominan/ } \\
\text { Dominant } \\
\text { species }\end{array}$ \\
\hline$<29,50$ & $-25,00$ & $-48,24$ & 0,01 & 1,13 & $\begin{array}{l}\text { Nemipterus } \\
\text { hexodon }\end{array}$ \\
\hline $29,60-36,50$ & $-25,08$ & $-45,75$ & 0,02 & 0,89 & $\begin{array}{l}\text { Leiognathus } \\
\text { splendens }\end{array}$ \\
\hline $36,60-43,50$ & $-26,41$ & $-46,17$ & 0,01 & 0,46 & $\begin{array}{l}\text { Leiognathus } \\
\text { splendens }\end{array}$ \\
\hline $43,60-50,50$ & $-29,65$ & $-44,39$ & 0,01 & 0,39 & $\begin{array}{l}\text { Nemipterus } \\
\text { japonicus }\end{array}$ \\
\hline $50,60-57,50$ & $-26,66$ & $-44,93$ & 0,01 & 0,28 & $\begin{array}{l}\text { Nemiptorus } \\
\text { nematophorus }\end{array}$ \\
\hline $57,60-64,50$ & $-28,29$ & $-44,66$ & 0,01 & 0,39 & $\begin{array}{l}\text { Nemipterus } \\
\text { japonicus }\end{array}$ \\
\hline $64,60-71,50$ & $-31,71$ & $-45,82$ & 0,01 & 0,00 & - \\
\hline $71,60-78,50$ & $-37,57$ & $-41,43$ & 0,00 & 0,36 & $\begin{array}{l}\text { Priacanthus } \\
\text { tayenus }\end{array}$ \\
\hline$>78,60$ & $-34,69$ & $-42,34$ & 0,01 & 0,00 & - \\
\hline
\end{tabular}

Analisis Koresponsi Jenis Ikan pada Setiap Selang Kelas Kedalaman

Berdasarkan pada analisis korespondensi dengan matrik 9 selas kelas kedalaman dan 90 spesies ikan akan menggambarkan hubungan antara spesies pada selang kelas kedalaman menghasilkan 2 dimensi berdasarkan pada nilai variabel yang terbesar. Dimensi 1 memiliki eigenvalue 0,6768 atau memiliki enersia $36,68 \%$, artinya dimensi 1 mempengaruhi $36,68 \%$ dari hubungan yang ada. Dimensi 2 memiliki eigenvalue 0,4493 atau nilai inersia $25,68 \%$ yang artinya dimensi 2 mempengaruhi $25,68 \%$ dari hubungan yang ada. Dua dimensi ini sudah cukup untuk memberikan gambaran yang ada antara selang kelas yang ada dengan spesies ikan. Nama-nama spesies dapat dilihat pada Lampiran 1 sesuai dengan kode-kode pada Gambar 7.

Berdasarkan pada Gambar 7 dapat dijelaskan bahwa ada jenis ikan-ikan tertentu yang hanya menghuni selang kelas kedalaman perairan tertentu, meskipun spesiesspesies tersebut tidak dominan. Contoh spesies-spesies yang hanya ditemukan pada kelompok I sekaligus yaitu 
pada selang kedalaman 1 adalah $D$. kuhli (Drk), Lutjanus sebae (Lss), spesies ini hanya ditemukan pada kedalaman kurang dari 29,5 m dengan nilai hambur balik dasar perairan terkecil $(-55,51 \mathrm{~dB})$. Spesies-spesies yang dikelompokkan pada kelompok II yaitu spesiesspesies yang hanya menghuni selang kedalaman 2 dan 3 (30 sampai dengan 43,5 m) dengan nilai hambur balik
-54,84 sampai dengan $-54,47 \mathrm{~dB}$ yaitu Psedorhombus sp. (Pss), Gerres oyena (Gro). Contoh spesies pada kelompok III yaitu spesies-spesies yang ditemukan hanya pada selang kedalaman $4,5,6$, dan 8 , yaitu pada kedalaman 44 sampai dengan $85,5 \mathrm{~m}$ dengan nilai hambur balik $-54,42$ sampai dengan $-52,30 \mathrm{~dB}$, contoh spesies Aluterus sp. (Als), Alectis (Alc).

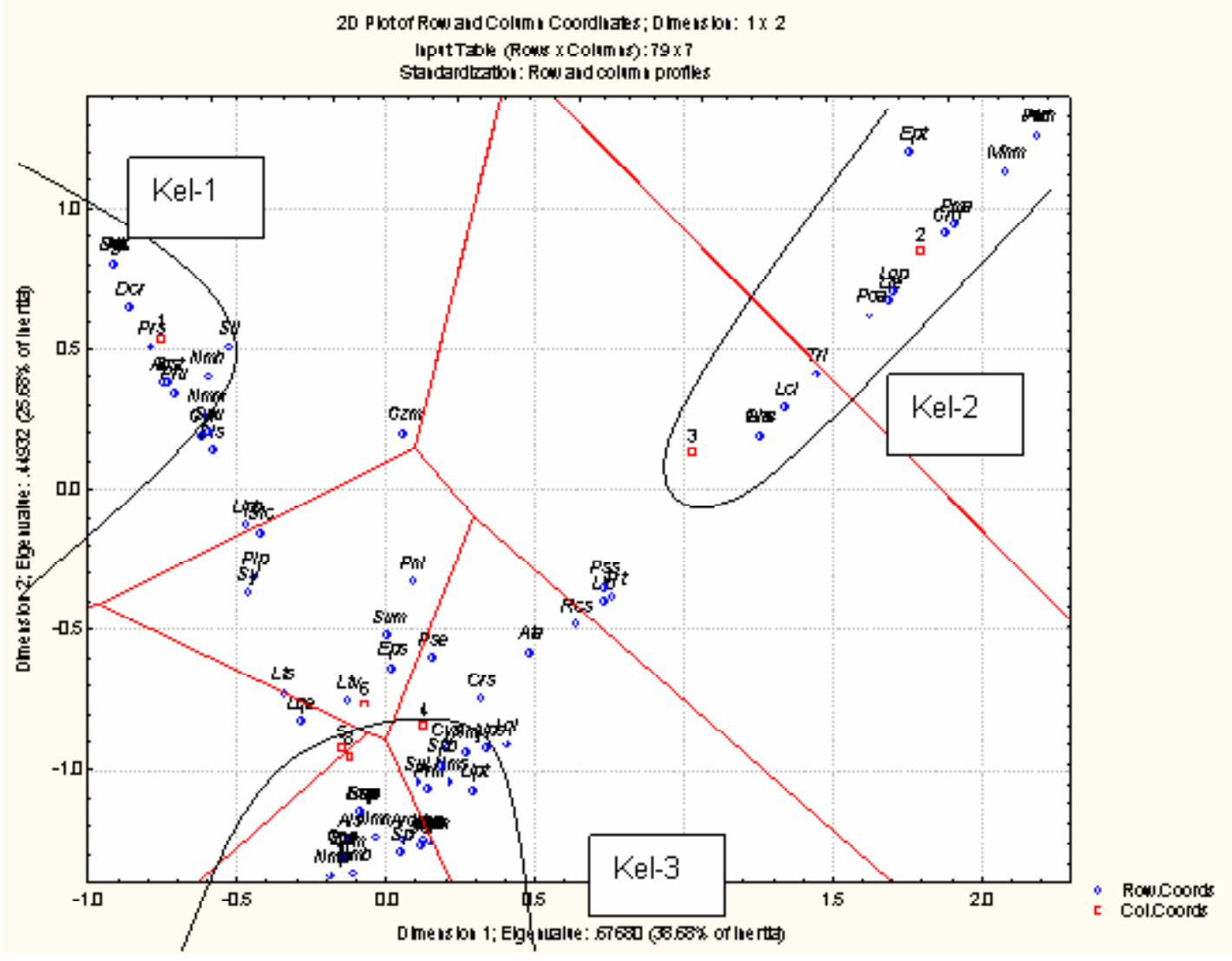

Gambar 7.

Analisis korespondensi spesies ikan pada setiap selang kelas kedalaman.

Figure 7. Correspondence analysis of fish species at depth class range.

\section{KESIMPULAN}

1. Hasil deteksi hidroakustik terhadap dasar perairan menunjukkan penyebaran nilai hambur balik dasar perairan di Laut Jawa yang tidak merata. Penyebaran nilai target strength menunjukkan ikan-ikan besar berada di perairan yang dalam, namun densitas ikan demersal hasil deteksi hidroakustik semakin menurun di wilayah yang menjauhi pantai.

2. Spesies ikan hasil sapuan traw/ pada setiap selang kelas kedalaman menunjukkan adanya spesies dominan, dan analisis koresponsi menunjukkan adanya pengelompokkan jenis ikan.

\section{PERSANTUNAN}

Kegiatan dari hasil riset pengkajian kelimpahan dan distribusi sumber daya ikan pelagis kecil dan demersal di perairan Laut Jawa dan sekitarnya, T.A. 2002 dan 2005, di Anggaran Pendapatan Belanja Negara.

Ucapan terima kasih pada Balai Riset Perikanan Laut, Muara Baru-Jakarta yang telah memberikan ijin untuk mengikuti survei di Laut Jawa, juga pada awak kapal Riset Mutiara IV, yang telah membantu saat pengambilan data di lapangan. 


\section{DAFTAR PUSTAKA}

Badrudin. 2004. Penelitian sumber daya ikan demersal. Departemen Kelautan dan Perikanan. Jakarta.

Hufiadi \& Nurdin, E. 2006. Laju tangkapan dan kepadatan stok ikan demersal di perairan sekitar Pulau Berhala, Selat Malaka. Seminar Nasional Perikanan Tangkap. Departemen Pemanfaatan Sumber Daya Perikanan. Fakultas Perikanan dan IImu Kelautan. Institut Pertanian Bogor. Bogor. 70-77 p.

Labropoulou M. \& Papaconstantianou C. 2004. Community structure and diversity of demersal fish assemblages: The role of fishery. SCI. MAR. 68 (Suppl.1):215-226.

Manik, M. H. 2006. Pengukuran akustik scattering strength dasar laut dan identifikasi habitat ikan dengan echosounder. Seminar Nasional Perikanan Tangkap. Departemen Pemanfaatan Sumber Daya Perikanan. Fakultas Perikanan dan IImu Kelautan. Institut Pertanian Bogor. Bogor. 128-133 p.

Nasoetion, A. H. \& Barizi. 1985. Metode statistika untuk penarikan kesimpulan. P.T. Gramedia. Jakarta.

Nontji, A. 1993. Laut Nusantara. Penerbit Djembatan. Jakarta.

Ona, E. \& Godo, O. R. 1990. Fish reaction to trawling noise: The significance for trawl sampling. Rapp. P. v. Roun. Cons. Int. Explor. Mar. 189: 159-168.
Rajali, H., Gambang A. C., Hamid I. A., Hasan R. B., Awang D., Shiomi K., \& Fujiwara, S. 2006. Stock assessment by hydroakustic method in the South China Sea Area II: Sabah, Sarawak, Brunei Darussalam. http://www.mfrdmd.org.my/sumber/ pelagis-eez/executive summery-eez.htm (21 Oktober 2006).

Ridho, M. R, Suman A., Eidman M., Kaswadji R. F., Nurhakim S. 2002. Jurnal IImu-IImu Perairan dan Perikanan Indonesia. IX (2): 111-119.

Sadhotomo, B. 2006. Review of environmental features of the Java Sea. Indonesian Fisheries Resources Journal. 12 (2): 129-157.

Siwabessy, P. J. W. 2001. An investigation of relationship between seabed type and benthic and bentho pelagic biota using acoustic techniques. Curtin University of Technology. Australia. (Tesis).

Sumiono, B., Badrudin, \& Widodo A. 2003. Pengkajian kelimpahan dan distribusi sumber daya ikan demersal di perairan Laut Cina Selatan. Forum Pengkajian Stok Ikan Laut Indonesia. Jakarta. 57-65 p.

Wigan, M. 1998. The last of the hunter gatherers (fisheries crisis at sea). Swan Hill Press. London.

Wyrtki, K. 1961. Physical oceanography of the Southeast Asian waters. The University of California. California. 
Lampiran 1. Kode-kode nama-nama spesies

Apenddix 1. Name species codes

\begin{tabular}{|c|c|c|c|}
\hline Spesies & Singkatan & Spesies & Singkatan \\
\hline Abalistes stellaris & Abs & Nemipterus hexodon & $\mathrm{Nmh}$ \\
\hline Abudefduf sp. & $A b$ & Nemipterus japonicus & $\mathrm{Nmj}$ \\
\hline Alectis & Alc & Nemipterus marginathus & $\mathrm{Nmm}$ \\
\hline Alepes djeddaba & Ald & Nemipterus mesoprion & $\mathrm{Nms}$ \\
\hline Aluterus sp. & Als & Nemipterus peronii & $\mathrm{Nmp}$ \\
\hline Anodonstoma chacunda & Anc & Nemipterus tambuloides & $\mathrm{Nmt}$ \\
\hline Ariomma indica & Arc & Nemiptorus nematophorus & $\mathrm{Nmn}$ \\
\hline Arius thalassinus & Art & Pampus argenteus & Pma \\
\hline Athropus atropus & Ata & Parascolopsis sp. & Prs \\
\hline Atule & Atu & Parupenus sp. & Pru \\
\hline Carangoides malabaricus & Crm & Penhia macrocephal & Pnm \\
\hline Caranx sexfasciatus & Crs & Pentapodus setosus & Pns \\
\hline Caranx sp. & Csp & Pentaprion longimanus & Pnl \\
\hline Chirocentrus nudus & Chn & Plectorhyncus pictus & Plp \\
\hline Carcharhinus sealei & Cas & Pomadasys argereus & Poa \\
\hline Cephalopolis & Cep & Pomaddasys hasta & Poh \\
\hline Cynoglosus sp. & Cys & Priacanthus macracanthus & Prm \\
\hline D.kuhli & Drk & Priacanthus tayenus & Prt \\
\hline Dasyiatis sp. & Dss & Psetodes erumai & Pse \\
\hline Decapterus macrosoma & Dmc & Pseudorhombus sp. & Pss \\
\hline Decapterus ruselli & Dcr & Rachycntron sp. & Rcs \\
\hline Dussumiera acuta & Dsa & Rastrelliger kanagurta & Rsk \\
\hline Ephinephellus fasciatus & Epf & Saurida longimanus & Sul \\
\hline Ephinephellus sexatilies & Epx & Saurida micropectoralis & Sum \\
\hline Ephinephellus sp. & Eps & Saurida tumbil & Sut \\
\hline Ephinephellus tauvina & Ept & Scoplopsis tenopterus & Sct \\
\hline Fistularia sp. & Fsp & Scoplopsis vosmeri & Scv \\
\hline Formio niger & Frn & Seriolina nigrofasciata & Srn \\
\hline Gazza minuta & Gzm & Secutor insidiator & Sci \\
\hline Gerres oyena & Gro & Selar crumenophthalmus & Slc \\
\hline Gnathanodon sp. & Gns & Selaroides leptolepis & SII \\
\hline Gymn & Gym & Seriolina nigrofasciata & Srn \\
\hline Gymnocranius robinsoni & Gyr & Siganus canalikulatus & Sgc \\
\hline Lactarius lactarius & $\mathrm{Lcl}$ & Silago sp. & Sls \\
\hline Leiognathus bindus & Lib & Sphyraena baracuda & $\mathrm{Spb}$ \\
\hline Leiognathus equlus & Lie & Sphyraena sp. & Sps \\
\hline Leiognathus smithursti & Lis & Stolephorus indicus & Sti \\
\hline Leioqnathus elongatus & Lqe & Surida undosquamis & Suu \\
\hline Leioqnathus splendens & Lqp & Synodus sp. & Sy \\
\hline Leiognqthus leuciscus & Lql & Terapon therap & Trt \\
\hline Lutjanus malabaricus & Ltm & Trichiurus lepturus & $\mathrm{Trl}$ \\
\hline Lutjanus sebae & Lts & Upenus bensasi & Upb \\
\hline Lutjanus vitta & Ltv & Upenus Iuzonius & Upl \\
\hline Mene maculata & Mnm & Upenus sulphureus & Ups \\
\hline Nemipterus bathybus & $\mathrm{Nmb}$ & Upenus tragula & Upt \\
\hline
\end{tabular}

